\title{
Food Insecurity and Its Sociodemographic Correlates among Afghan Immigrants in Iran
}

\author{
Nasrin Omidvar', Mahmoud Ghazi-Tabatabie², Rasoul Sadeghi², \\ Fatemeh Mohammadi', Mohammad Jalal Abbasi-Shavazi ${ }^{3}$

\begin{abstract}
'Department of Community Nutrition, Faculty of Nutrition Sciences and Food Technology, Shahid Beheshti University of of Demography, University of Tehran, Iran and Australian Demographic and Social Research Institute,
\end{abstract} \\ Medical Sciences, Tehran, Iran; ${ }^{2}$ Department of Demography, Faculty of Social Science, University of Tehran, Iran; ${ }^{3}$ Department \\ Australian National University, Canberra, Australia
}

\begin{abstract}
The study determined the prevalence of food insecurity and its sociodemographic determinants among Afghan immigrants in two major cities of Iran. This cross-sectional study was conducted on a sample of 310 adult females from immigrant Afghan households in Tehran $(n=155)$ and Mashhad $(n=155)$, who were recruited through multistage sampling. Data were collected through face-to-face interviews, using a questionnaire. Food security was measured by a locally-adapted Household Food Insecurity Access Scale. More than $60 \%$ suffered from moderate-to-severe food insecurity, 37\% were mildly food-insecure while about $23 \%$ were food-secure. Food insecurity was significantly more prevalent in female-headed households, households whose head and spouse had lower level of education, belonged to the Sunni sect, and those with illegal residential status, unemployment/low job status, not owning their house, low socioeconomic status (SES), and living in Mashhad. Prevalence of food insecurity was relatively high among Afghan immigrants in Iran. This calls for the need to develop community food security strategies for ensuring their short- and long-term health.
\end{abstract}

Key words: Afghan, Immigrants; Food insecurity; Sociodemographic determinants; Iran

\section{INTRODUCTION}

In the history of the modern world, the situation in Afghanistan has resulted in one of the largest displacements of mankind in search of safety and a better life (1). Migratory movements of the Afghans to Iran have a long history. Transitory migration of the Afghans to Iran motivated by economic differences has occurred since the nineteenth century. Also, Shiite Afghans have been making pilgrimages to Iran for several hundred years. However, the modern history of Afghan immigration to Iran started in 1979. Since then, Afghan immigration to Iran has been primarily motivated by the direct and indirect effects of war, insecurity, threat to female honour (namoos), unemployment, and

Correspondence and reprint requests:

Dr. Mahmoud Ghazi-Tabatabie

Associate Professor and Head

Department of Demography

Faculty of Social Science

University of Tehran

Tehran, Iran

Email: smghazi@ut.ac.ir

Fax: (98) 2188012524 inflation. In this process, Iran, as one of the most concentrated destination of immigrants and refugees, has hosted around 3 million Afghan migrants and refugees in the past three decades. In spite of the repatriation programme, still around 2 to 2.5 million Afghan immigrants, both legal and illegal, live in Iran (2-4).

Health and nutrition status of immigrants is of concern from public-health point of view. Food insecurity that is characterized by "limited access to or availability of nutritionally-adequate, culturallyrelevant, and safe food and/or limited or uncertain ability to acquire food in socially acceptable ways" (5), has long been a problem for the most vulnerable and under-represented segments of the population, including foreign immigrants and refugees. However, research in this field is rare and, thus, the need for assessing the extent of food insecurity among such vulnerable and hard-to-reach segments of the population is of great importance (6).

Food insecurity represents a major public-health concern and is a useful index of health and wellbeing because it is associated with poverty, ill-health, 
poor dietary intake (e.g. low intake of fruits and vegetables), limited social capital, and depressive disorders (7). The dynamics of food insecurity reflect the composition and financial circumstances of families (8). In case of immigrants, different factors are identified as being responsible for food insecurity, including economic constraints posed by poverty, low-wage employment, job insecurity, education, and marginal social position as well as the obligation to send money to family remaining in their country of origin in some cases. Also, many immigrants face additional challenges due to lack of valid immigration documents and fear of being deported. Therefore, immigrants are distinguished from many non-immigrants because they face additional pressure that may strain already-limited household food resources. Based on results of previous studies, immigrant families are more likely than native families to face food insecurity. Research also suggests that food insecurity is higher among lessacculturated immigrants (9-10).

Despite the large volume and long trend of Afghan migratory movements to Iran, little information is available on nutritional status of Afghan immigrants in Iran (11). Thus, the present study was undertaken to examine the extent of food insecurity and its correlates among Afghan immigrants in two metropolitan cities Tehran and Mashhad in 2010.

\section{MATERIALS AND METHODS}

\section{Study design}

This cross-sectional study was conducted in the framework of a larger study on the adaptation of Afghan immigrants in Iran (3). The study was performed in Tehran and Mashhad-two metropolitan cities of Iran-during February and March 2010. Based on 2006 Census, the majority of Afghan immigrants (72\%) resided in urban areas of the country while only less than 3\% were in refugee camps. The major provinces that host these immigrants include Tehran (32.7\%), Khorasan Razavi (Mashhad) (13.3\%), Isfahan (11.7\%), and Sistan-Baluchistan (9.3\%) (3). Selection of Tehran and Mashhad as the study sites was due to the sizeable population of Afghans in these two cities.

\section{Subjects}

A sample of 310 adult females (aged 20 years and above) from Afghan households residing in Tehran $(\mathrm{n}=155)$ and Mashhad ( $\mathrm{n}=155)$ was recruited. Multistage sampling was done through a two-stage procedure. In the first stage, stratified clustersampling procedure was used for selecting the lo- cation and blocks with high concentration of the Afghans in each city. In the second stage, chainreferral (snowball) sampling technique was used. Drawing a random sample of immigrants is not possible; thus, snowball sampling technique is the most widely-applied method of survey among immigrants.

The respondents were chosen from married women (housewives) who were directly involved in food preparation in the households.

\section{Data collection}

Data were collected through face-to-face interviews by six trained Afghan female interviewers who were college students or graduates. The interviewers were trained prior to data collection in a oneday workshop conducted by the research team at the Faculty of Social Science in the University of Tehran. Through this workshop, the interviewers were trained on the purpose of the study, sampling procedures, considerations in administration of the questionnaire, and other field-related factors.

Data on sociodemographic characteristics, including age, sex, level of education, and occupational status of household head and spouse as well as family-size, expenditure, residency, and living conditions, were gathered through a structured questionnaire.

Household socioeconomic status (SES) was defined by composite indicators, including household assets (housing material, car, motorcycle, computer, colour television, freezer, vacuum cleaner, washing machine, and furniture) and average monthly expenditure per capita. We used principal component analysis (PCA) to construct the SES score and, based on the range of the score, the households were categorized into three SES categories: high, middle, and low.

In addition, socioeconomic position of the neighbourhood was also categorized into three categories: high, middle, and low, based on socioeconomic level of the area where the subjects resided. Neighbourhood index of socioeconomic development was determined using information from the 2006 Census in Iran on average education and occupational attainment by residents of that neighbourhood and their access to facilities.

\section{Measurement of food insecurity}

Food security was measured at the household level. A locally-adapted HFIAS (Household Food Insecurity Access Scale) developed by USAID's Food and 
Nutrition Technical Assistance (FANTA) project was used in measuring food security in each household. The scale consisted of 9 items with 4 frequency options that classified households into secure, mild, moderate, and severe food-insecure. Steps taken in adaptation and validation of the scale is presented elsewhere (12).

\section{Statistical analysis}

Data were analyzed by SPSS software (version 16.0). Descriptive statistics were used in examining the association between food security status and each of the independent variables, using analysis of variance and $\chi^{2}$-test.

The likelihood of being food-insecure was determined by regression analyses, using binary logistic regression. Also, multinomial logistic regression was used in estimating the association between selected household characteristics and food security status. In this case, households were classified as 'food-secure', 'mild-to-moderately food-insecure', and 'severely food-insecure'.

\section{RESULTS}

\section{Characteristics of the sample}

The respondents included 310 Afghan women with mean age of $35.3 \pm 11$ years, who were either head of the household $(\mathrm{n}=25)$, or spouse $(\mathrm{n}=278)$ and, in a few cases $(n=7)$, older unmarried girls in the household. The characteristics of respondents and their households are displayed in Table 1.

\section{Household food insecurity status}

Distribution of responses to the nine questions in HFIAS is presented in Table 2. More than $40 \%$ of women reported worrying that food would run out while $16 \%$ had experienced actual lack of any food within the household, and less than $10 \%$ had gone to sleep hungry more than once. As shown in the figure, more than $60 \%$ Afghan households included in the study suffered from moderate-tosevere food insecurity while only $23 \%$ were foodsecure.

\section{Food insecurity and sociodemographic correlates}

Bivariate analysis showed no significant association between the age of respondent as well as age of the household head and food security status while food security status was significantly correlated with the duration of residency in Iran, average household monthly expenditure per capita, and SES (Table 3).

\begin{tabular}{|c|c|c|c|}
\hline $\begin{array}{l}\text { Sociodemographic } \\
\text { characteristics }\end{array}$ & $\begin{array}{c}\text { Fre- } \\
\text { quency }\end{array}$ & $\begin{array}{l}\text { Per- } \\
\text { centage }\end{array}$ & Mean \pm SD \\
\hline \multicolumn{4}{|c|}{ Age (years) } \\
\hline $15-<30$ & 123 & 39.7 & $35.3 \pm 11.2$ \\
\hline $30-<45$ & 112 & 36.1 & \\
\hline$\geq 45$ & 75 & 24.2 & \\
\hline \multicolumn{4}{|l|}{ Marital status } \\
\hline Married & 280 & 90.3 & \\
\hline Widow & 23 & 7.4 & \\
\hline Unmarried & 7 & 2.3 & \\
\hline \multicolumn{4}{|l|}{ Educational levels } \\
\hline No education & 120 & 38.7 & \\
\hline Primary & 117 & 37.7 & \\
\hline Secondary & 32 & 10.3 & \\
\hline $\begin{array}{l}\text { Diploma and } \\
\text { higher }\end{array}$ & 41 & 13.2 & \\
\hline \multicolumn{4}{|l|}{ Occupational status } \\
\hline Unemployed & 287 & 92.6 & \\
\hline Employed & 23 & 7.4 & \\
\hline \multicolumn{4}{|l|}{ Religion } \\
\hline Shiite & 225 & 72.6 & \\
\hline Sunni & 85 & 27.4 & \\
\hline \multicolumn{4}{|l|}{ Birthplace } \\
\hline Afghanistan & 244 & 78.7 & \\
\hline Iran & 66 & 21.3 & \\
\hline \multicolumn{4}{|l|}{$\begin{array}{l}\text { Duration of residency } \\
\text { in Iran (years) }\end{array}$} \\
\hline$<10$ & 42 & 13.5 & $22.9 \pm 10.2$ \\
\hline $10-<20$ & 72 & 23.2 & \\
\hline $20-<30$ & 122 & 39.4 & \\
\hline$\geq 30$ & 74 & 23.9 & \\
\hline \multicolumn{4}{|l|}{ Legal status } \\
\hline Documented & 245 & 79.0 & \\
\hline Undocumented & 65 & 21.0 & \\
\hline \multicolumn{4}{|l|}{ City } \\
\hline Tehran & 155 & 50.0 & \\
\hline Mashhad & 155 & 50.0 & \\
\hline
\end{tabular}

There was no relationship between household food insecurity and marital status, birth place, and city of residency (Table 4). However, prevalence of food insecurity significantly increased with increasing household-size, in female-headed households, those households whose head and spouse had lower educational level, those belonging to the Sunni sect, those with illegal residential status, unemployed/low job status, those who did not own 
Table 2. Responses to nine questions in HFIAS applied among Afghan households in Iran, 2010

\begin{tabular}{|lcccc|}
\hline \multirow{2}{*}{ HFIAS questions } & \multicolumn{4}{c|}{ Options } \\
\cline { 2 - 5 } & No & Rarely & Sometimes & Often \\
\hline Q1: Worry about food & $185(59.7)$ & $56(18.1)$ & $29(9.4)$ & $40(12.9)$ \\
Q2: Unable to eat preferred foods & $102(32.9)$ & $70(22.6)$ & $77(24.8)$ & $61(19.7)$ \\
Q3: Eat just a few kinds of foods & $109(35.2)$ & $51(16.5)$ & $83(26.8)$ & $67(21.6)$ \\
Q4: Eat foods that really do not want to eat & $104(33.5)$ & $71(22.9)$ & $80(25.8)$ & $55(17.7)$ \\
Q5: Eat a smaller meal & $217(70.0)$ & $53(17.1)$ & $25(8.1)$ & $15(4.8)$ \\
Q6: Eat fewer meals in a day & $254(81.9)$ & $28(9.0)$ & $21(6.8)$ & $7(2.3)$ \\
Q7: No food of any kind in the household & $261(84.2)$ & $34(11.0)$ & $14(4.5)$ & $1(0.3)$ \\
Q8: Go to sleep hungry & $280(90.3)$ & $21(6.8)$ & $7(2.3)$ & $2(0.6)$ \\
Q9: Go a whole day and night without eating & $304(98.1)$ & $4(1.3)$ & $2(0.6)$ & $0(0.0)$ \\
\hline Figures in parentheses indicate percentages & \multicolumn{5}{c}{} \\
\hline
\end{tabular}

Figure. Food insecurity among Afghan households in Tehran and Mashhad, 2010

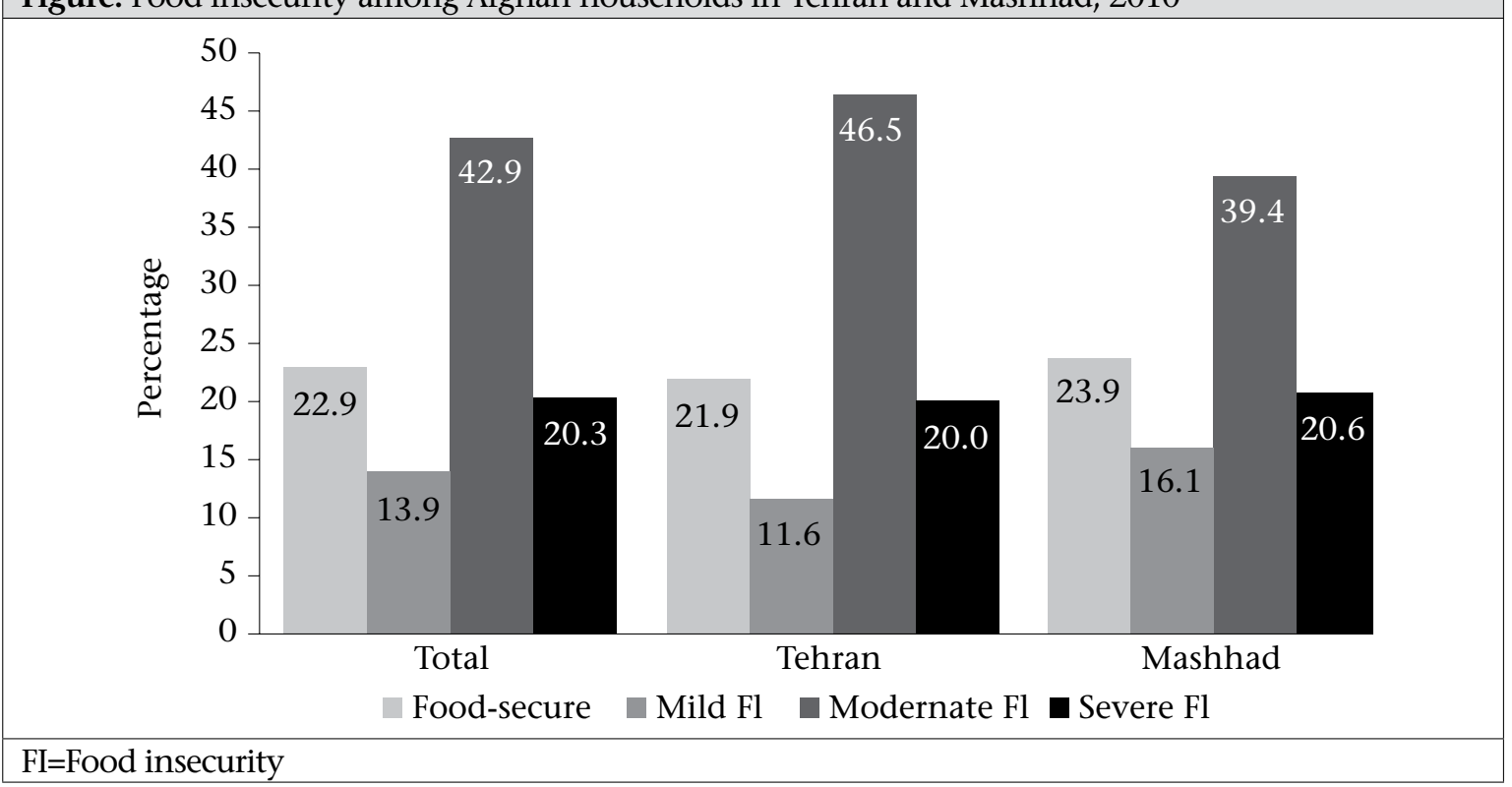

their house, and low SES, and households in poor neighbourhoods. Food insecurity decreased with increase in the duration of residency in Iran and the level of household SES.

Binary and multinomial logistic regression analyses were used in investigating the association of demographic and socioeconomic factors with food insecurity. Table 5 presents the estimated odds ratios (OR) and 95\% CI of binary logistic regression analysis. The dependent variable is a dichotomous measure of food security versus food insecurity. The model was initially fitted with fifteen factors, of which nine were found to be significantly associated with food insecurity. These included educational level of respondent, age and gender of household head, type of job, household monthly expenditure, housing tenure, SES, economic situation of the neighbourhood, and city context. No significant differences were observed in the prevalence of food insecurity by occupational status, religion, birthplace, legal status, household-size, and the duration of residency in Iran.

As shown in Table 5, educational level was a protective factor against food insecurity. The probability of household food security was higher when household heads had a high school diploma and higher level of education compared to those with lower educational level. Also, labourers and farmers had more prevalence of food insecurity compared to persons with salaried occupations. With increase in age of the household head, the likelihood of being food-insecure increased. Female-headed households were more likely to be food-insecure than households headed by males.

The probability of food insecurity in the households with rented house was higher than those 


\begin{tabular}{|c|c|c|c|c|}
\hline \multirow[b]{2}{*}{ Variable } & \multicolumn{4}{|c|}{ Food security status (Mean \pm SD) } \\
\hline & $\begin{array}{l}\text { Food secu- } \\
\text { rity }(\mathrm{n}=71)\end{array}$ & $\begin{array}{l}\text { Mild insecu- } \\
\text { rity }(\mathrm{n}=43)\end{array}$ & $\begin{array}{c}\text { Moderate } \\
\text { insecurity } \\
(\mathrm{n}=133)\end{array}$ & $\begin{array}{l}\text { Severe inse- } \\
\text { curity }(\mathrm{n}=63\end{array}$ \\
\hline Age of respondent (years) & $33.6 \pm 11.2$ & $34.6 \pm 11.6$ & $36.2 \pm 10.9$ & $35.8 \pm 11.8$ \\
\hline Age of head of household (years) & $40.1 \pm 12.8$ & $42.0 \pm 14.3$ & $42.6 \pm 12.7$ & $43.2 \pm 14.2$ \\
\hline Household-size (numbers)* & $5.1 \pm 2.0$ & $6.3 \pm 2.7$ & $6.0 \pm 2.5$ & $6.6 \pm 2.6$ \\
\hline Duration of residency in Iran (years) & $26.2 \pm 8.1$ & $22.3 \pm 9.2$ & $22.5 \pm 10.7$ & $20.4 \pm 11.3$ \\
\hline $\begin{array}{l}\text { Average household monthly expendi- } \\
\text { ture per capita (US\$) }\end{array}$ & $125 \pm 98.6$ & $67.3 \pm 40.8$ & $64 \pm 31.8$ & $55.8 \pm 33.2$ \\
\hline Score of socioeconomic status $s^{\star \star}$ & $59.6 \pm 10.4$ & $49.7 \pm 8.0$ & $46.7 \pm 8.3$ & $44.2 \pm 8.9$ \\
\hline
\end{tabular}

who owned their house. The prevalence of food insecurity was significantly higher in households in poor neighbourhoods than in those with high SES. In addition, the result showed that food insecurity among Afghan households in Mashhad was high compared to those in Tehran.

Multinomial logistic regression was used in estimating the association between selected individual/ household characteristics and household food security status. In this analysis, we classified household food security level as 'food-secure', 'mild-to-moderately food-insecure', and 'severely food-insecure'. Results of multinomial logistic regression analyses are displayed in Table 6 . The first set of coefficients predicts severe food insecurity versus food security, the second set of coefficients compares mild-tomoderate food insecurity versus food security, and the third set of coefficients compares severe versus mild-to-moderate food insecurity.

Compared to food-secure households, low level of education, being Sunni, labourer, and farmer, having older age, and female gender of the household head, having less than US\$ 50 monthly household expenditure per capita, having renting house, belonging to low social class, living in poor neighbourhood, and living in Mashhad increased the risk of severe food insecurity. In turn, living in Iran for 20-30 years decreased this risk.

When comparing mild-to-moderately food-insecure households with food-secure ones, the major predictors of food insecurity included low educational level, older age, and female gender of the household head as well as less than US\$ 50 monthly expenditure per capita, having renting house, low-to-middle SES, living in neighbourhood with poor-to-middle SES, and living in Mashhad.
Comparison of severely food-insecure households with mild or moderately food-insecure group showed that being Sunni, unemployed, labourer and farmer, and having less than US\$ 50 monthly expenditure per capita increased the risk of severe food insecurity while living in Iran for 20-30 years and living in neighbourhood with middle SES decreased the risk.

\section{DISCUSSION}

To the best of our knowledge, this is one of the first studies on food security status of Afghan refugees in Iran. The result indicated high prevalence of food insecurity among the studied households. The extent of food insecurity observed in this study is higher than those reported on immigrant Afghans in Pakdasht (11), which is a low-income city, located south of Tehran and considerably higher than estimates on Iranian households (12) as well as Latino immigrant families in the USA (13). However, food insecurity levels observed among Afghan immigrants in Iran are comparable with those of migrant and seasonal farm worker (MSFW) households on the USA-Mexico border (14). The Afghan immigrants face a high risk of food insecurity due to poverty, low human capital, limited access to resources and good job opportunities, and structural barriers to integration into Iranian society.

Analysis of influencing factors showed that immigrant households can be affected by food insecurity in different ways depending on their sociodemographic characteristics and economic situations. The major predictors identified for food insecurity in Afghan households in the present study included older age and female gender of household head, low educational level, being Sunni, low job status, low SES, having less than US\$ 50 monthly expendi- 


\begin{tabular}{|c|c|c|c|c|}
\hline Variable & $\begin{array}{c}\text { Food } \\
\text { security }\end{array}$ & $\begin{array}{c}\text { Mild } \\
\text { insecurity }\end{array}$ & $\begin{array}{l}\text { Moderate } \\
\text { insecurity }\end{array}$ & $\begin{array}{c}\text { Severe } \\
\text { insecurity }\end{array}$ \\
\hline \multicolumn{5}{|l|}{ Head of household* } \\
\hline Male $(\mathrm{n}=285)$ & $70(24.6)$ & $41(14.4)$ & $118(41.4)$ & $56(19.6)$ \\
\hline Female $(\mathrm{n}=25)$ & $1(4.0)$ & $2(8.0)$ & $15(60.0)$ & $7(28.0)$ \\
\hline \multicolumn{5}{|l|}{ Marital status } \\
\hline Married (n=280) & 69 (24.6) & $41(14.6)$ & $116(41.4)$ & $54(19.3)$ \\
\hline Widowed (n=23) & $1(4.3)$ & $1(4.3)$ & $14(60.9)$ & $7(30.4)$ \\
\hline Unmarried (n=7) & $1(14.3)$ & $1(14.3)$ & $3(42.9)$ & $2(28.6)$ \\
\hline \multicolumn{5}{|l|}{ Educational levels ${ }^{\star *}$} \\
\hline No education $(n=120)$ & $14(11.7)$ & $15(12.5)$ & $58(48.3)$ & $33(27.5)$ \\
\hline Primary $(n=117)$ & 28 (23.9) & 19 (16.2) & 49 (41.9) & $21(17.5)$ \\
\hline Secondary $(\mathrm{n}=32)$ & $12(37.5)$ & $2(6.3)$ & $14(10.5)$ & $4(12.5)$ \\
\hline Diploma and higher $(\mathrm{n}=41)$ & 17 (41.5) & 7 (17.1) & $12(29.3)$ & $5(12.2)$ \\
\hline \multicolumn{5}{|l|}{ Occupational status* } \\
\hline Unemployed (n=287) & $66(23.0)$ & $35(12.2)$ & $125(43.6)$ & $61(21.3)$ \\
\hline Employed $(n=23)$ & $5(22.7)$ & $8(34.8)$ & $8(34.8)$ & $2(8.7)$ \\
\hline \multicolumn{5}{|l|}{ Religion** } \\
\hline Shiite $(\mathrm{n}=225)$ & $58(25.8)$ & $33(14.7)$ & $99(44.0)$ & 35 (15.6) \\
\hline Sunni $(\mathrm{n}=85)$ & $13(15.3)$ & $10(11.8)$ & $34(40.0)$ & $28(32.9)$ \\
\hline \multicolumn{5}{|l|}{ Birthplace* } \\
\hline Afghanistan (n=244) & $52(21.3)$ & $34(13.9)$ & $107(43.9)$ & $51(20.9)$ \\
\hline $\operatorname{Iran}(n=66)$ & $19(28.8)$ & 9 (13.6) & $26(39.4)$ & $12(18.2)$ \\
\hline \multicolumn{5}{|l|}{ Duration of residency in Iran (years) ${ }^{\star *}$} \\
\hline$<10$ & $5(11.9)$ & $7(16.7)$ & $19(45.2)$ & $11(26.2)$ \\
\hline $10-<20$ & $8(11.1)$ & $10(13.9)$ & 30 (41.7) & $24(33.3)$ \\
\hline $20-<30$ & 38 (31.1) & 17 (13.9) & $54(44.3)$ & $13(10.7)$ \\
\hline$\geq 30$ & $20(27.0)$ & $9(12.2)$ & $30(40.5)$ & $15(20.3)$ \\
\hline \multicolumn{5}{|l|}{ Legal status* } \\
\hline Documented (n=245) & $63(25.7)$ & $35(14.3)$ & $103(42.0)$ & $44(18.0)$ \\
\hline Undocumented $(\mathrm{n}=65)$ & $8(12.3)$ & $8(12.3)$ & $30(46.2)$ & $19(29.2)$ \\
\hline \multicolumn{5}{|l|}{ Educational levels of husband* } \\
\hline No education $(n=58)$ & $7(12.1)$ & $9(15.5)$ & $29(50.0)$ & $13(22.4)$ \\
\hline Primary $(n=101)$ & $19(18.8)$ & $17(16.8)$ & 45 (44.6) & $20(19.8)$ \\
\hline Secondary $(n=57)$ & $20(35.1)$ & $6(10.5)$ & $22(38.6)$ & $9(15.8)$ \\
\hline Diploma and higher $(\mathrm{n}=64)$ & $23(35.5)$ & 9 (14.1) & $20(31.3)$ & $12(18.8)$ \\
\hline \multicolumn{5}{|l|}{ Occupation of husband ${ }^{* *}$} \\
\hline Unemployed $(\mathrm{n}=14)$ & $2(14.3)$ & $3(21.4)$ & $6(42.9)$ & $3(21.4)$ \\
\hline Labourer, Farmer $(\mathrm{n}=88)$ & $8(9.1)$ & $16(18.2)$ & $42(47.7)$ & $22(25.0)$ \\
\hline Freelancer, Shopkeeper (n=157) & 47 (29.9) & 19 (12.1) & $63(40.1)$ & $28(17.8)$ \\
\hline Employee, Teacher, Clergy ( $n=12)$ & $5(41.7)$ & $3(25.0)$ & $4(33.3)$ & $0(0)$ \\
\hline Doctor, Employer $(n=5)$ & $5(100.0)$ & $0(0)$ & $0(0)$ & $0(0)$ \\
\hline \multicolumn{5}{|l|}{ Housing tenure ${ }^{* *}$} \\
\hline Ownership (n=66) & $26(39.4)$ & $10(15.2)$ & $23(34.8)$ & 7 (10.6) \\
\hline Renting $(n=244)$ & 45 (18.4) & 33 (13.5) & $110(45.1)$ & $56(23.0)$ \\
\hline \multicolumn{5}{|l|}{ Socioeconomic status of household $* \star *$} \\
\hline Low $(n=89)$ & $5(5.6)$ & $10(11.2)$ & $46(51.7)$ & $28(31.5)$ \\
\hline Middle (n=182) & 35 (19.2) & $30(16.5)$ & $83(45.6)$ & 34 (18.7) \\
\hline High $(n=39)$ & $31(79.5)$ & $3(7.7)$ & $4(10.3)$ & $1(2.6)$ \\
\hline \multicolumn{5}{|l|}{ Socioeconomic position of location ${ }^{\star \star *}$} \\
\hline Low $(n=143)$ & $15(10.5)$ & $21(14.7)$ & $71(49.7)$ & $36(25.2)$ \\
\hline Middle (n=109) & $27(24.8)$ & 15 (13.8) & $52(47.7)$ & $15(13.8)$ \\
\hline High $(n=58)$ & $29(50.0)$ & $7(12.1)$ & $10(17.2)$ & $12(20.7)$ \\
\hline \multicolumn{5}{|l|}{ City } \\
\hline Tehran $(n=155)$ & 34 (21.9) & 18 (11.6) & $72(46.5)$ & $31(20.0)$ \\
\hline Mashhad (n=155) & 37 (23.9) & $25(16.1)$ & $61(39.4)$ & $32(20.6)$ \\
\hline
\end{tabular}




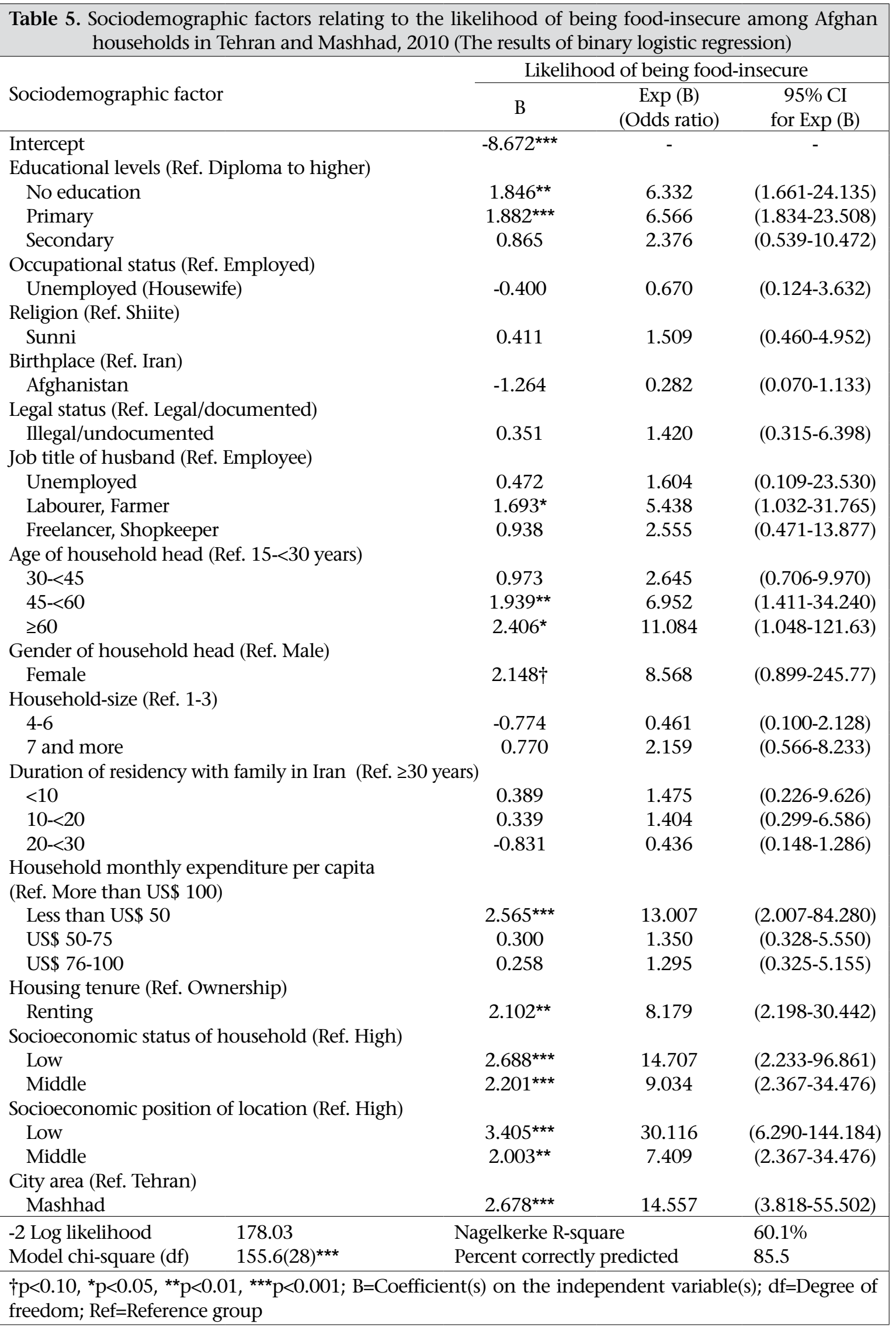




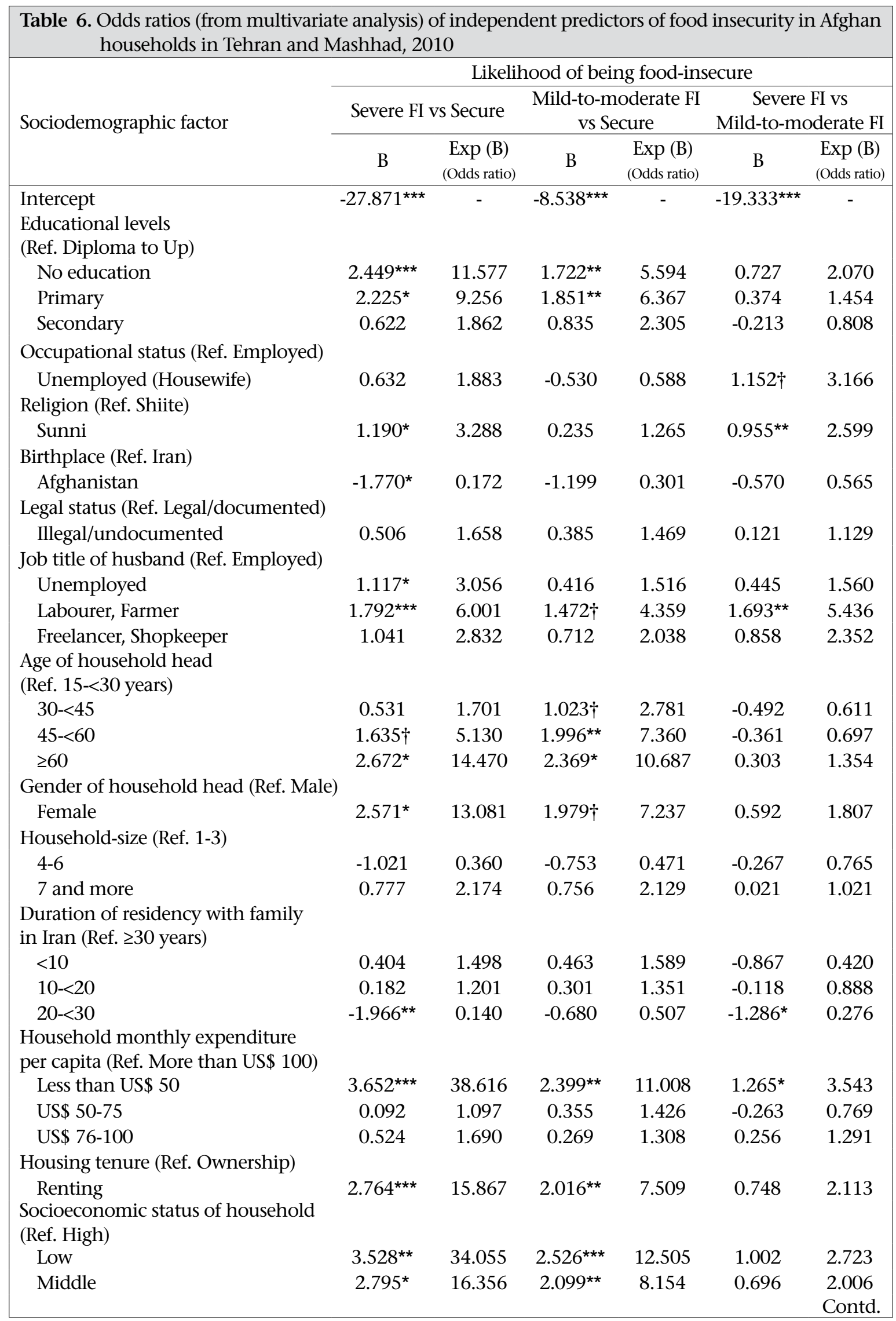




\begin{tabular}{|c|c|c|c|c|c|c|}
\hline \multirow{3}{*}{ Sociodemographic factor } & \multicolumn{6}{|c|}{ Likelihood of being food-insecure } \\
\hline & \multicolumn{2}{|c|}{ Severe FI vs Secure } & \multicolumn{2}{|c|}{$\begin{array}{l}\text { Mild-to-moderate FI } \\
\text { vs Secure }\end{array}$} & \multicolumn{2}{|c|}{$\begin{array}{c}\text { Severe FI vs } \\
\text { Mild-to-moderate FI }\end{array}$} \\
\hline & B & $\begin{array}{l}\operatorname{Exp}(\mathrm{B}) \\
\text { (Odds ratio) }\end{array}$ & B & $\begin{array}{l}\text { Exp (B) } \\
\text { (Odds ratio) }\end{array}$ & B & $\begin{array}{l}\text { Exp (B) } \\
\text { (Odds ratio) }\end{array}$ \\
\hline \multicolumn{7}{|l|}{$\begin{array}{l}\text { Socioeconomic position of location } \\
\text { (Ref. High) }\end{array}$} \\
\hline Low & $2.841^{\star *}$ & 17.140 & $3.538^{\star \star *}$ & 34.382 & -0.696 & 0.499 \\
\hline Middle & 0.948 & 2.580 & $2.220^{\star \star \star}$ & 9.211 & $-1.273^{*}$ & 0.280 \\
\hline \multicolumn{7}{|l|}{ City area (Ref. Tehran) } \\
\hline Mashhad & $3.119^{\star \star *}$ & 22.626 & $2.563^{\star \star \star}$ & 12.978 & 0.556 & 1.743 \\
\hline -2 Log likelihood & 403.23 & & & & & \\
\hline Pseudo R-square & $56.2 \%$ & & & & & \\
\hline Model chi-square (df) & $204.7(56)^{*}$ & & & & & \\
\hline
\end{tabular}

ture per capita, having renting house, living in poor neighbourhood, and living in Mashhad. A recent study on determinants of food insecurity among Iranian households in the city of Tehran identified residency in medium- and low-SES districts, low education and job level of household head, lower income, expenditure, and facilities in the house as the major determinants of food insecurity among the studied population (12). In Pakdasht study, the low level of education of the household head and spouse (mother), sizeable number of young children in the family, and female gender of the head were also shown to be major predictors of household food insecurity (11). We have identified old age, belonging to the Sunni sect, living in a rented house and in Mashhad to be additional risk factors for food insecurity among Afghan refugees.

One of the important findings of the present study is that food insecurity was inversely associated with the length of stay in Iran. Previous studies had shown higher prevalence of household food insecurity among the recent immigrant households in Canada (6,15-16) and the USA (8-9). Longer length of residency has been shown to be related to increased acculturation, adaptation, and livelihood strategies.

Current evidence suggests the association between chronic household food insecurity and adverse health (17-19), including increased morbidity and mortality (20-22) and obesity (23-25) or underweight both in adults (26) and children (27). Although we could not measure health or nutritional status of the subjects, such findings re-emphasize the importance of social policy for immigrants in the country.

\section{Limitations}

This study had several limitations; the small sample-size and lack of random sample selection could prevent generalization to the total population of Afghan immigrants in Iran. Though not ideal, convenience sampling was necessary because no sampling frame is available for this sensitive and hard-to-reach population. Also, the high level of food insecurity observed among the Afghans in this study could be partly due to the selectivity of the Afghans in Iran; all are labourers, with low level of SES.

Income data were not collected in the study because of the difficulty for immigrants to estimate incomes that vary monthly. Assessment of dietary intake or other indicators of nutritional status were not possible in the frame of the present study.

\section{Conclusions}

This research provides new insights into the prevalence and factors associated with food insecurity among immigrant and refugee households in Iran.

Despite their longstanding presence of the Afghans in Iran, they remain excluded from key aspects of social, political and economic life in the country. The Afghans in Iran are employed mostly in jobs requiring little or no skills because of structural barriers and low human capital, and they are mostly concentrated in low socioeconomic settings. The prevalence of food insecurity among Afghan immigrants is unacceptably high. Afghan refugees and immigrants are a potentially vulnerable group, and our results suggest a need for more thorough monitoring of their health and well-being. 
Policy-makers need to reconsider access to food programmes in light of the level of food insecurity and its short- and long-term consequences. Future studies are needed to evaluate and compare the results with those of the Afghan and Iranian counterparts. Also, further studies are needed to monitor levels of food insecurity in immigrant households and the strategies that they adopt for coping.

\section{ACKNOWLEDGEMENTS}

This research was partially supported by Faculty of Social Sciences, University of Tehran under Grant No. 3105005-1-04. We thank the Afghan students in the University of Tehran and Mashhad, who conducted the interviews. Valuable comments from Tahmeed Ahmed are gratefully acknowledged.

\section{REFERENCES}

1. Tober D. My body is broken like my country: identity, nation, and repatriation among Afghan refugees in Iran. Iran Stud 2007;40:263-85.

2. Abbasi-Shavazi MJ, Sadeghi R. The adaptation of second-generation Afghans in Iran: empirical findings and policy implications. Washington, DC: Middle East Institute, 2011.14 p. [MEI-FRS working paper]. (http://www.refugeecooperation.org/publications/ afghanistan/pdf/05_jalal.pdf, accessed on 5 August 2013).

3. Abbasi-Shavazi MJ, Sadeghi R. The adaptation of Afghan immigrants in Iran. Tehran: Department of Demography, University of Tehran, 2010:23-45.

4. Glazebrook D, Abbasi-Shavazi MJ. Being neighbors to Imam Reza: pilgrimage practices and return intentions of Hazara Afghans living in Mashhad, Iran. Iran Stud 2007;40:187-201.

5. Food and Agriculture Organization. Rome declaration on world food security and world food summit plan of action, Paper presented on World Food Summit by Food and Agriculture Organization, Rome, 13-17 November 1996. (http://www.fao.org/ docrep/003/w3613e/w3613e00.HTM, accessed on 9 August 2013).

6. Vahabi M, Damba C, Rocha C, Montoya EC. Food insecurity among Latin American recent immigrants in Toronto. J Immigr Minor Health 2011;13:929-39.

7. Hadley C, Zodhiates A, Sellen DW. Acculturation, economics and food insecurity among refugees resettled in the USA: a case study of West African refugees. Public Health Nutr 2007;10:405-12.

8. Hofferth SL. Persistence and change in the food security of families with children, 1997-99. Washington, DC: Economic Research Service, 2004. 27 p.
9. Capps R, Horowitz A, Fortuny K, Bronte-Tinkew J, Zaslow M. Young children in immigrant families face higher risk of food insecurity. Washington, DC: Child Trends, 2009. 7 p. (Child Trends Research Brief No. 2009-07).

10. Capps R, Ku L, Fix M, Furgiuele C, Passel J, Ramchand $\mathrm{R}$ et al. How are immigrants faring after welfare reform? Preliminary evidence from Los Angeles and New York City. Washington, DC: Urban Institute, 2002. $57 \mathrm{p}$.

11. Sheykholeslam R, Abdollahi Z, Salarkia N, Kavehi Z, Abdollahi M, Kalantari $\mathrm{N}$ et al. Food security assessment of urban Afghan refugee populations in Pakdasht, Iran. Tehran: World Food Program, 2008. 38 p.

12. Mohammadi F, Omidvar N, Houshiar-Rad A, Khoshfetrat M-R, Abdollahi M, Mehrabi Y. Validity of an adapted household food insecurity access scale in urban households in Iran. Public Health Nutr 2012;15:149-57.

13. Quandt SA, Shoaf JI, Tapia J, Hernández-Pelletier M, Clark HM, Arcury TA. Experiences of Latino immigrant families in North Carolina help explain elevated levels of food insecurity and hunger. J Nutr 2006;136:2638-44.

14. Weigel MM, Armijos RX, Hall YP, Ramirez Y, Orozco $R$. The household food insecurity and health outcomes of U.S.-Mexico border migrant and seasonal farmworkers. J Immigr Minor Health 2007;9:157-69.

15. Canada. Health Canada. Household food insecurity in Canada in 2007-2008: key statistics and graphics. Ontario: Health Canada. (http://www.hc-sc.gc.ca/fnan/surveill/nutrition/commun/insecurit/key-statscles-2007-2008-eng.php, accessed on 12 July 2011).

16. Hadley C, Sellen D. Food security and child hunger among recently resettled Liberian refugees and asylum seekers: a pilot study. J Immigr Minor Health 2006;8:369-75.

17. Coleman-Jensen AJ. U.S. food insecurity status: toward a refined definition. Soc Indic Res 2010;95:215-30.

18. Sulaiman-Hill CM, Thompson SC. Selecting instruments for assessing psychological wellbeing in Afghan and Kurdish refugee groups. BMC Res Notes 2010;3:237.

19. Vissandjee B, Desmeules M, Cao Z, Abdool S, Kazanjian A. Integrating ethnicity and migration as determinants of Canadian women's health. BMC Womens Health 2004;4(Suppl 1):S32.

20. Stuff JE, Casey PH, Szeto KL, Gossett JM, Robbins JM, Simpson PM et al. Household food insecurity is associated with adult health status. J Nutr 2004;134:2330-5.

21. Siefert K, Heflin CM, Corcoran ME, Williams DR. Food insufficiency and physical and mental health 
in a longitudinal survey of welfare recipients. J Health Soc Behav 2004;45:171-86.

22. Vozoris NT, Tarasuk VS. Household food insufficiency is associated with poorer health. J Nutr 2003;133:120-6.

23. Adams EJ, Grummer-Strawn L, Chavez G. Food insecurity is associated with increased risk of obesity in California women. J Nutr 2003;133:1070-4.

24. Bhattacharya J, Currie J, Haider S. Poverty, food insecurity, and nutritional outcomes in children and adults. J Health Econ 2004;23:839-62.

25. Townsend MS, Peerson J, Love B, Achterberg C, Mur- phy SP. Food insecurity is positively related to overweight in women. J Nutr 2001;131:1738-45.

26. Isanaka S, Mora-Plazas M, Lopez-Arana S, Baylin A, Villamor E. Food insecurity is highly prevalent and predicts underweight but not overweight in adults and school children from Bogotá, Colombia. J Nutr 2007; 137:2747-55

27. Casey PH, Simpson PM, Gossett JM, Bogle ML, Champagne CM, Connell $\mathrm{C}$ et al. The association of child and household food insecurity with childhood overweight status. Pediatrics 2006;118:e1406-13. 